\title{
Genetics and breeding of sheep in Brazil
}

\section{Concepta McManus ${ }^{1,3}$, Samuel Rezende Paiva ${ }^{2,3}$, Ronyere Olegário de Araújo ${ }^{1}$}

\author{
${ }^{1}$ Faculdade de Agronomia e Medicina Veterinária, Universidade de Brasília, Brasília - DF, 7090-900. \\ 2 EMBRAPA Recursos Genéticos e Biotecnologia, Brasília - DF, 70770-900. \\ ${ }^{3}$ Bolsista de Produtividade CNPq.
}

\begin{abstract}
Studies in genetics and breeding of sheep in Brazil have increased significantly in recent years. These involve research in characterization, breeding and crossing sheep using new technologies available incorporating both classical quantitative and molecular genetics. Improvements in statistical techniques, computational resources as well as analysis of DNA and gaps in present knowledge and opportunities for possible research are pointed out. There is a need for greater interaction between various groups working in the country as well as interactions with other disciplines such as Geographical Information Systems, Statistics, Bioinformatics, as well as biological studies such as physiology and proteomics.
\end{abstract}

Key Words: breed, disease, heat tolerance, history, molecular markers, Ovis aries

\section{Genética e melhoramento de ovinos no Brasil}

RESUMO - Estudos em genética e melhoramento de ovinos no Brasil têm aumentado significativamente nos últimos anos. Estes envolvem pesquisa em caracterização, criação e cruzamento de ovinos utilizando as novas tecnologias disponíveis, incorporando tanto a genética quantitativa clássica e molecular. São abordadas sugestões para melhorias nas técnicas de estatística, nos recursos computacionais, bem como na análise de DNA e nas lacunas no conhecimento atual e possibilidades de possíveis investigações. Há uma necessidade de maior interação entre vários grupos de trabalho no país, bem como as interações com outras disciplinas, como Sistemas de Informação Geográfica, Estatística, Bioinformática, bem como estudos biológicos, como fisiologia e proteômica.

Palavras-chave: doenças, marcadores moleculares, Ovis aries, raça, tolerância ao calor

\section{Introduction}

Sheep have been present in Brazil for almost 500 years but their numbers have not increased to the same extent as other farm animals. This has been largely due to herd structure (smallholders), perceived use of sheep as a secondary culture and lack of interest from major research groups.

Some recent papers (Ribeiro et al., 2006) have pointed to a lack of research on sheep breeding and genetics, but this is not the case. Brazil has several technologies available for use in genetic and environmental studies, but there is a need to fill in some gaps in the present range of studies being undertaken. The present paper looks to research carried out, concentrating on those produced in Brazil on several aspects of sheep genetics and breeding. It also looks to the future. Breeders and farmers need to improve a wide range of traits, not just production but product quality and welfare related fitness, as well as heat and disease resistance. Many of these traits are difficult or expensive to measure. The overall plan of action used by researchers is to combine gene mapping technologies, gene expression studies in target tissues, production data and modern bioinformatics tools with available and expanded genome sequences, to determine the origin of genetic variation in important traits in livestock species.

\section{History of sheep}

Domestic breeds of sheep are most likely descended from the wild mouflon (Ovis aries orientalis) from Asia. Sheep were originally kept for meat, milk and skin (Ensminger \& Parker, 1986), but it wasn't until 3,500 B.C. that man learned to spin wool (Smith et al., 1997). The very early breeds of sheep had two coats, an outer coat of kemp, or bristly hair, and an under coat of fine wool or down that is shed in the spring. The bristly hair has been gradually bred out of most sheep so that they have coats that are all wool.

As sheep herding spread over Asia and Europe, wool became one of the most commonly used fibers for clothing and an important product in trade. Spain developed the 
Merino breed of sheep for its high quality fleece, in the $12^{\text {th }}$ Century and maintained a monopoly on the breed. This helped to create the great wealth that Spain used to launch its explorations of the New World. The export of a single ewe was punishable by death, until Napoleon's invasion of Spain in 1786 opened the doors to other nations interested in obtaining this breed (Ryder, 1983). Thus, the first sheep brought to the new world had lower quality wool. It seems likely that sheep, as a source of food, were brought from Africa (Angola or Nigeria) or Cape Verde which was a transit point in the Atlantic slave trade (Primo, 2000).

The first domestic animals (including sheep, goats, cattle, poultry, horses and pigs) came to South America with Christopher Colombo on his second voyage in 1493 (Primo, 2004). They disembarked in La Española (today Dominican Republic and Haiti), which served as a dissemination point for the rest of the Antilles and the continent. There are no specific registers of sheep being taken directly to Brazil from Europe (Rodero et al., 1992), but sheep were introduced to Brazil via Paraguay (by Ñuflo de Chaves in 1549, Felipe de Cáceres in 1569), as well as Argentina (Juan de Garay in 1580). Sheep were among the animals registered in all “capitanias” by Pero de Magalhães in 1576 (Gândavo, 1980) and were sent to Bahia in 1587 (Sousa, 1938). Although there are controversies, it is believed that the breeds were the Churra, Churra Bordaleira, Merino and Lacha (Mariante \& Cavalcante, 2006).

The wool industry, in particular, grew and in 1875, Brazil exported 1,142,750 lbs of wool to the United States (Ripley \& Dana, 1875). In the $20^{\text {th }}$ century, the invention of artificial fibers took some of the market for wool. Table 1 shows the development of sheep farming in Brazil during the last century. There was an increase in 24.4\% from 1935 to 2007 , lower than that in cattle numbers over the same period.

Both hair and wool sheep can be found in Brazil. Breeds are categorized by the type of their wool while hair sheep are similar to the early domesticated sheep, kept before wool breeds were developed, and are raised for meat and pelts. It is estimated that at present $90 \%$ of hair sheep are found in Africa and 10\% in the Americas.

\section{Sheep breeds and characterization}

There are 27 or more breeds or ecotypes of sheep in Brazil, but only eleven are increasing in number (see Mariante et al., 2003) and new breeds are being imported. Breed descriptions are available from ARCO (www.arcoovinos.com.br). According to the Ministry of Agriculture (11 ${ }^{\text {th }}$ March 2010, pers comm) seven Insemination centers maintain breeding rams (three in São Paulo State). The most popular breeds are Dorper and Santa Inês, with Minas Gerais and São Paulo having the most animals (Table 2).

While almost all exotic breeds are registered with the Ministry of Agriculture, several naturalized Brazilian breeds are not. Regulations governing genealogical register of animals (Brazilian Law 4716/1965) included the wording "genealogical register of domestic animals" which led to various interpretations. In 2008, the Commission on Agriculture, Animal Production, Supply and Rural Development in the House of Deputies in the National Congress approved a change in the wording in the Law proposal 7210/2006 to "genealogical register of animals of agricultural interest", which should facilitate the registration of smaller populations, ecotypes and breeds.

Taking into account rapid genetic erosion (Scherf, 2000) and the importance of Animal Genetic Resources (AnGR) for the future (Notter, 1999), it may not be possible to wait for specific and detailed information on available breeds and ecotypes. Studies should concentrate on phenotypic characterization, as well as efficient control of production and health data. Molecular characterization and economic viability of breeds in production systems should then follow.

Characterization on Brazilian breeds can be morphological (Carneiro et al., 2009) or genetic (Paiva et al., 2005). Most naturalized Brazilian breeds are hair type (Santa Inês, Morada Nova, Somali, Barriga Preta, Cariri, Fat Tail) with Crioula Lanada and Bergamasca being wool type. Hair breeds are known to produce the best skins in ruminants, and have a high demand in the clothing and show trade (Jacinto et al., 2004). While the benefits of high

Table 1 - Evolution of sheep population (number and \%) in Brazil

\begin{tabular}{lcccc}
\hline & $1912^{1}$ & $1935^{1}$ & $2007^{2}$ & $\%$ increase \\
\hline North & $39,560(0.003)$ & $51,000(0.004)$ & $521,640(0.032)$ & $1,318.60$ \\
Northeast & $5,797,380(0.551)$ & $3,668,000(0.281)$ & $9,286,258(0.572)$ & 160.18 \\
Centre-west & $124,020(0.012)$ & $162,300(0.012)$ & $1,086,238(0.067)$ & 875.86 \\
South & $3,815,930(0.363)$ & $8412900(0.645)$ & $4,603,241(0.283)$ & 120.63 \\
Southeast & $738,880(0.070)$ & $754,900(0.058)$ & $742078(0.046)$ & 100.43 \\
Total & 10515770 & 13049100 & 16239455 & 154.43 \\
\hline
\end{tabular}

${ }^{1}$ Pinheiro Jr. (1973); ${ }^{2}$ FNP Instituto (2009). 
Table 2 - Distribution of rams in Insemination centers in Brazil by breed and State

\begin{tabular}{|c|c|c|c|c|c|c|c|}
\hline & Bahia & Ceará & Minas Gerais & Pernambuco & Paraná & São Paulo & Total \\
\hline Dorper & 4 & & 4 & & 5 & 11 & 24 \\
\hline Dorset & & & 1 & & & & 1 \\
\hline Ile de France & & & & & & 2 & 2 \\
\hline Merino & & & & 1 & & & 1 \\
\hline Santa Inês & 4 & 3 & 9 & & & 7 & 23 \\
\hline Texel & & & 1 & & & 1 & 2 \\
\hline Total & 8 & 3 & 15 & 1 & 5 & 21 & 53 \\
\hline
\end{tabular}

quality sheep products are well known at present, Brazil exports in terms of sheep products are negligible but imports range from leather/skin (mainly from Australia, African and Middle East countries in excess of 500t per year) to wool and about 7000t of meat in natura from Uruguay (MAPA, 2009).

\section{Molecular studies}

As well as breed characterization (Paiva et al., 2005), there a number of uses for molecular studies in sheep breeding. These include (Dodds et al., 2007) marker or genotype assisted selection, parentage confirmation or exclusion, traceability, detection of disease vectors, and providing individuals to niche markets. As it is still in its infancy, sheep breeding has the advantage that it need not go through the same difficulties as cattle breeding.

Mixed model methodology (Henderson, 1984) is the preferred tool for animal breeding improvement. This depends on the inclusion of pedigree information on the evaluated animals, so genealogical connections between animals, free from errors, are of primary concern. Parental misidentification can reduce heritability estimates, and covariances interaction between fixed and random effects also affected (Senneke et al., 2004). Error in paternity identification has been shown to vary from $10 \%$ to $20 \%$ (Banos et al., 2001; Visscher et al., 2002; Weller et al., 2004; Jiménez-Gamero et al., 2006) in developed countries and have been shown to surpass 35\% in Gyr cattle in Brazil (Baron et al., 2002). Parentage-assignation errors are human mistakes. This can occur during labelling semen straws for artificial insemination, interchange of young at birth and multiple sire-breeding groups, as well as keying animal identification code into the herd book (Weller et al., 2004).

The certification of pedigrees using DNA markers is a viable option. The Ministry of Agriculture approved the normative $74 / 2004$ to register laboratories to carry out genetic identification using DNA. Eight microsatellite markers were suggested for sheep and goat breeds. Souza et al. (2006) tested this panel against other 23 markers suggested in a study of 5 Santa Inês herds (Table 3). These results show that some of the markers suggested by MAPA could be substituted by others that are more informative for Brazilian breeds.

Examining mtDNA haplotypes in naturalized and commercial sheep in Brazil, Paiva et al. (2005a) found that all animals were related to the European haplotype except two Dorper animals which had African origin (classification sensu Hiendleder et al., 1999), confirmed by sequencing. This high frequency of European haplotypes confirms the historical events in the introduction of this paper, but the role of African animals needs to be studied better. These polymorphisms may be used in selection programs, as well as in cloning and gene expression studies, if economic traits linked to these haplotypes are found.

At least five large haplotypes were found in the sheep species (Meadows et al., 2006). To identify phylogenetic and phylogeographic relationships between eleven naturalized and commercial Brazilian sheep breeds, 588 base pairs (bp) were sequenced from the first half and 524 bp from the second half of the control region of mitochondrial DNA (mtDNA). Considering only the second

Table 3 - Probabilities of paternity exclusion using various panels of microsatellite markers

\begin{tabular}{lcccc}
\hline Number of markers & Panel & PIC & PE1 (\%) & PE2 (\%) \\
\hline 23 & Complete & 0.712 & 99.999 & 99.999 \\
15 & Highest PIC values & 0.783 & 99.992 & 99.999 \\
13 & Highest PIC values & 0.798 & 99.981 & 99.999 \\
10 & Highest PIC values & 0.811 & 99.907 & 99.999 \\
08 & Highest PIC values & 0.821 & 99.708 & 99.990 \\
08 & MAPA & 0.680 & 97.378 & 99.799 \\
\hline
\end{tabular}

Source: Souza et al. (2006); PIC: polymorphic information content; PE1: probability of exclusion knowing neither of parents; PE2: probability of exclusion knowing at least one of the parents. 
half, a total of 38 haplotypes were found in 49 animals and 57 GenBank sequences (Silvério et al., 2006). The nucleotide diversity value was 0.005 , an intermediate value between 0.00318 found by Meadows et al. (2005) and 0.00881 found by Pedrosa et al. (2005). The AMOVA values were greater than those found with nuclear markers and Brazilian naturalized breeds showed deviations in the Fu/FS neutrality test $(\mathrm{p}<0.01)$, suggesting that demographic expansion of this population is occurring.

Two independent polymorphisms were typed on the Y chromosome in Brazilian sheep breeds ( $N=190)$ : one SNP on the promoter region of the SRY gene and one microsatellite locus. Meadows et al. (2006) determined the haplotypes for these polymorphisms studying various sheep breeds worldwide. Of the seven haplotypes known to exist in Ovis aries, five were found in Brazilian breeds and apparently a new allele was found only in Brazilian breeds (Table 4). These studies may be considered additional evidence (as seen later with microsatellites) of the recent influence of the Bergamasca and other commercial breeds on the formation of the Santa Inês (or vice-versa) (H8 and new haplotypes). Some Santa Inês animals showed a haplotype common to other Brazilian breeds and African hair sheep (H6).

Using network analysis (Bandelt et al., 1999) the relationship between these haplotypes was studied. Two formation events of Brazilian naturalized breeds were seen, an older event (H27) with European breeds and a more recent event (H28) with only Brazilian breeds. A haplotype (H15) was observed, common in Mexican Creole, in Crioula Lanada Brasileira, Corriedale and Spanish Aragonesa, reiterating common ancestry of Latin American wool Creole sheep with those from the Iberian Peninsula.

Figure 1 shows the evolution and utilization of some markers in sheep in Brazil. All major technologies are in use. The main objectives in the beginning of the genetic

Table 4 - Haplotype frequencies on Y chrosmossome in 10 sheep breeds in Brazil

\begin{tabular}{|c|c|c|c|c|c|c|}
\hline \multirow[b]{2}{*}{ Breed } & \multicolumn{6}{|c|}{ Haplotype (Meadows et al., 2006) } \\
\hline & $\mathrm{H} 4$ & H5 & H6 & H7 & H8 & Novo \\
\hline Santa Inês & & & 03 & & 42 & 01 \\
\hline Brazilian Bergamasca & 01 & & & & 16 & 02 \\
\hline Rabo Largo & & & 19 & 01 & & \\
\hline Morada Nova & & & 03 & & & \\
\hline Brazilian Somali & & & 01 & & & \\
\hline Hampshire & 05 & 07 & & & & \\
\hline Ile de France & & 07 & & & 03 & \\
\hline Corriedale & & & & & 02 & \\
\hline Damara & & & 03 & & & \\
\hline Dorper & & & 04 & & & \\
\hline
\end{tabular}

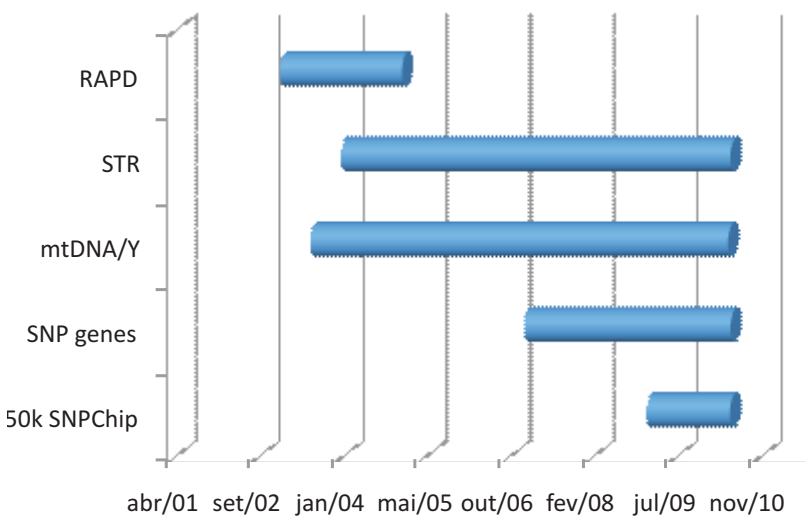

Figure 1 - Brazilian sheep genetic characterization program using molecular markers.

characterization efforts were to quantify the genetic diversity within and among breeds of the same species in order to identify the patterns of genetic structure as well as to estimate the influence of commercial/specialized breeds in the local adapted stock. Today the goals to achieve are towards the management of the herds kept in the Conservation Nuclei and selection of germplasm donors to for the Animal Genome Bank. With the development of high-throughput platforms of SNPs markers, the future goals will be, among others: (1) development of customized SNP panels for traceability and genetic management of the herds; and (2) insertion of breeds with higher effective numbers in breeding programs, when wild genome selection actions will start.

\section{Genetic management of herds}

Microsatellite markers are available for sheep herd management. Using 19 microsatellite markers, Paiva et al. (2006) showed that $11.76 \%$ of total variation ( $\mathrm{p}<0.001$ ) was due to interbreed differences. The tree diagram obtained from Nei differences and Neighbor-joining algorithms divided breeds into three main groups: naturalized Brazilian breeds, exotic wool breeds and recently introduced African breeds. From a Bayesian analyzing using the Structure software, it was possible to identify a significant substructure in the Santa Inês (herds from Santa Inês high northeast versus herds from low Northeast and Centerwest) and Morada Nova (red versus white varieties). These results (Paiva et al., 2005), together with inter-breed variability indices show that although Santa Inês may be considered a breed it had several introgression events in its recent past, thereby being highly polymorphic with poor phenotypic definition (for example, multiple coat colours). Looking at Santa Inês populations, the tree branches were highly consistent (Souza et al., 2006). This pattern may have 
various causes, such as the breed standard being too broad, leaving margin for various interpretations, or crossbreeding. Therefore, any molecular marker association studies that include Santa Inês sheep should be preceded by a detailed genetic structure test so the results are not confused by ecotype. The fact that Bergamasca is situated within the hair sheep group indicates that this breed too may have suffered crossbreeding with hair sheep in the past.

Molecular markers may be used in breed certification as a strategy to monitor crossbreds in breed genealogical registers. This practice can reduce the frequency of important traits in the population and cause introgression undesirable traits. Taking the Santa Inês as an example, the breed standard defined by ARCO is ample and subject to interpretation. The register for Pure of Origin males is closed and so this breed is a strong candidate to lose traits associated with rusticity and adaptation in detriment to heterotic gains obtained through crosses with commercial exotic breeds. This may lead to the creation of different ecotypes registered throughout Brazil so that each type is selected and defined in relation to social-economic and political aspects instead of technical and scientific ones. These patterns have been identified using molecular markers (Paiva, 2005). These "New Santa Inês" may lose important traits such as gastro-intestinal parasite resistance (Amarante et al., 2004), pelt quality (Souza et al., 2003), as well as inherit non-desirable traits such as scrapie susceptibility (Ianella et al., 2009). The Suffolk breed, suspected as being used for the creation of this new animal, has a history of susceptibility to this illness (Heggebø et al., 2002).

Marker assisted selection (MAS) is used to identify animals at a young age that possess alteration in a particular trait using a genetic marker, or markers, associated with that trait. This may then be selected for (desirable trait) or against (non-desirable). The best markers for MAS are the causal mutations, but where these are not available; a haplotype that is in strong linkage disequilibrium with the causal mutation can also be used. Examples in sheep include the Inverdale marker to identify sheep with altered prolificacy (Galloway et al. 2000) and a GDF8 marker haplotype to identify sheep with a variant causing increased muscling (Johnson et al. 2005).

In tracing food products, genotyping can be used to identify breed of origin and, further, to track a piece of meat with specific desirable or undesirable properties back to the parents of the animals and thus farm of origin (Hayes et al. 2005; Plastow et al., 2007). Tracing could also be used in a breeding program as a way to select on desirable traits, for example meat quality, identified at final product level.

There are innumerous tools available for applying molecular markers in sheep breeding programs. For this to happen, there is a need to have an efficient and secure base for data collection, with standardized and systematic genealogical and production data recording. Without this molecular biology techniques will have little impact on national sheep breeding. The use of molecular information is increasing in sheep breeding programs, as systems become available to make use of this information and the cost of obtaining it are decreasing.

For genetic management of herds molecular markers can be used for genetic diversity analyses within herds for planning matings (ex., Paiva et al., 2005b); 2) Quantification of inbreeding within herds (Pariset et al., 2003); 3) semen quality; 4) Identification of carrier animals for alleles related to illnesses or traits of economic interest (Castro et al., 2006, Petroli, 2007); 5) parentage identification or confirmation.

A pilot study was carried out using the same 19 microsatellite loci as above in 191 animals of the conservation nucleus of Embrapa Tabuleiros Costeiros, Sergipe (Paiva et al., 2005b). Petroli et al. (2009) using thirteen microsatellite loci on chromosome 20 (where the Sheep Major Histocompatibility Complex is found) identified a reduction in heterozygosity over the years in a control herd compared to the whole population. This may be due to the repeated use of the same sires in this herd. Estimates of molecular coancestrality also indicated an increase in genetic similarity between individuals with the herd over the years. A high number of alleles occurred exclusively in the principal nucleus herd, but at a frequency lower than $10 \%$.

\section{Breeding programs}

While individual farmers or groups of farmers have carried out selection within individual flocks long term breeding programs are scarce in Brazil. Improvement in wool quality was the first objective (Ojeda, 1999). PROMOVI (Program for Sheep Genetic Improvement), based in Rio Grande do Sul State functioned between 1977 and 1995. With the international wool crisis at the beginning of the 1990s, the Corriedale breed was initially used as a dual purpose wool-meat breed, and later Hampshire Down, Suffolk, Ile de France and Texel were used to produce crossbred lambs for slaughter or in absorbent crosses. In 1991 ARCO altered PROMOVI to include a Growth Rate Test in Rio Grande do Sul, Santa Catarina, Paraná and São Paulo. The increase in interest in meat breeds, particularly in the 
Northeast of the country created a rift between ARCO and breeders in the Northeast of the country, which became the largest sheep producer.

Official, long term breeding programs for sheep in Brazil are still rare, mainly due to disorganization of the supply chain and disinterest on the part of farmers. At present several on-farm breeding programs are available in Brazil, including those run by Federal or State organs (p.ex. Genecoc - EMBRAPA Sheep and Goats; Santagen - UFPi; Promosi - EMEPA); Breeders Associations (Associação Sergipana de Criadores de Ovinos e Caprinos (ASCOC) together with USP) or private companies (OviGol® - AbacusBio Limited with Áries Reprodução e Melhoramento Genético Ovino Ltda; PROAG BRASIL Pecuaria Brasil Assessoria with CTAG - Technical center for genetic evaluation). Most of these programs are focused on the Santa Inez or Dorper breeds. Several of these groups also run on-farm or central tests such as Teste Centralizado de Desempenho de Cordeiros Tipo Carne TCDCTC by UFPel, Central test in UnB, growth tests by EMEPA (Sousa et al., 2008). These recording schemes and herd monitoring can help identify useful polymorphisms (Lôbo et al., 2009b).

Frequently breeding programs are confounded with simple estimation of Expected Progeny Differences and genetic evaluation. The formal definition of breeding objectives and selection criteria are frequently ignored in these programs. Some pioneering studies have been carried out (McManus et al., 2006; Morais et al., 2006; Pereira, 2010) showing the importance of preweaning traits in maintaining herd profits. Important pioneering projects are underway such as the "pre-improvement" of Morada Nova coordinated by EMBRAPA Sheep and Goats.

\section{Genetic parameters}

Breeding programs depend on accurate estimates of genetic parameters. These vary according to rearing systems, traits measured and breed used, as well as statistical models used for their calculation. In Brazil initial estimates were made for wool traits (Cardellino et al., 1987) while more recently growth and production traits dominate (Table 5). The variation in estimates is evident, showing the need for environment specific estimates and most recent estimates are based on the Santa Inês breed with other breeds and important traits such as reproduction and meat quality largely ignored.

Few studies are available on milk sheep production in Brazil. Corriedale and Milchschaf crosses have been used for milk production (Correa et al., 2006). Studies have also been carried out with Correidale (Souza et al., 2005), Lacaune (Nespolo et al., 2009), Santa Inês (Ribeiro et al., 2007) and Bergamácia (Sá et al., 2005; Emediato et al., 2009) for milk production, but genetic parameters or breed comparisons were not found.

\section{Heat tolerance and disease resistance}

According to Paiva et al. (2005), Santa Inês sheep in the Northeast and Center-west regions of Brazil can be classified in two sub-populations, with significantly different genetic standards. Crosses between the original Santa Inês and rams of the Suffolk breed were carried out in the Northeast to improve conformation of the breed and then successive selections for lack of wool, leading to an increase in the number of black and brown Santa Inês (McManus et al., 2009a). The Santa Inês breeders have concentrated their production on this animal with dark coat as standard for the breed. The white Santa Inês were

Table 5 - Summary of genetic parameters for sheep production traits in Brazil

\begin{tabular}{|c|c|c|c|c|}
\hline & Trait & $c^{2}$ & $\mathrm{~h}_{\mathrm{a}}^{2}$ & $\mathrm{~h}_{\mathrm{m}}^{2}$ \\
\hline \multirow{7}{*}{ Production } & Birth weight & $0.04-0.56$ & $0.12-0.22$ & 0.15 \\
\hline & Weaning weight & $0.00-0.81$ & $0.03-0.24$ & 0.09 \\
\hline & Yearling weight & $0.26-0.65$ & & \\
\hline & Growth birth weaning & $0.20-0.36$ & $0.06-0.56$ & 0.07 \\
\hline & Growth post weaning & $0.15-0.39$ & & \\
\hline & Litter birth weight & 0.15 & & \\
\hline & Litter weaning weight & 0.11 & & \\
\hline \multirow[t]{6}{*}{ Reproduction } & Age at first lambing & 0.04 & & \\
\hline & Lambing interval & $0.06-0.27$ & & \\
\hline & Gestation length & 0.10 & & \\
\hline & Litter size & $0.00-0.17$ & & \\
\hline & Julian lambing date & 0.05 & & \\
\hline & Lamb survival & $0.14-0.29$ & & \\
\hline
\end{tabular}

McManus \& Miranda (1998), Sousa et al. (1999), Silva \& Araujo (2000), Souza et al. (2000), Quesada et al. (2002), Carneiro et al. (2006), Lôbo et al. (2006), Sarmento et al. (2006), Sousa et al. (2006), Lôbo et al. (2009a). 
shown to be better adapted to heat stress (McManus et al., 2009a) with lower heart and breathing rates as well as lower rectal temperature. This may be due to higher reflectance of the coat with lower thermal radiance absorbance. The results found by these authors suggest that coat colour is more important than skin colour in terms of heat stress. There were no significant differences between black and brown Santa Inês or crossbred Bergamasca with Santa Inês in terms of heat tolerance.

Although Santa Inês are frequently marketed as being resistant to endoparasites, this was not confirmed in other studies (McManus et al., 2009b). Bricarello et al. (2005) also found no significant differences between Santa Inês and Ile de France lambs under mild $H$. contortus infection for haematological and biochemical profiles. This may be also due to poor productivity of the Santa Inês, as it has a lower growth rate than other terminal sire breeds. This lower genetic potential for growth affects resilience as less demand is put on nutritional partition of factors which affect both growth and resilience such as protein level in the feed (Louvandini et al., 2006).

In a study in the Federal District, McManus et al. (2009b) found that Morada Nova and Bergamasca had lowest Fecal Egg Count (FEC) for Strongylida, while lowest values for Strongyloides were found in Santa Inês and its cross with Ile de France (Ile X SI). The lowest Fecal Ovum Count (FOC) was found in Ile de France sheep. Genetic correlations in these sheep between the FEC or FOC and parasites species were low. Heritabilities varied from 0.09 to 0.31 . Nieto et al. (2003) used a threshold model and estimated heritability as 0.08 , but animals found to have higher FECs were dewormed, which may have affected this parameter, while Lôbo et al. (2009) found FEC heritability was extremely variable, increasing from 0.04 to 0.27 in the first challenge and from 0.01 to 0.52 during the second.

The results of studies carried out with animals produced by the crossing of resistant with susceptible breeds have demonstrated that the degree of resistance of the hybrids can vary as a function of the breeds evaluated, the age of the animals and whether the evaluations were from natural or artificial infections (Amarante et al., 2009). Important factors such as scrapie susceptibility, never before reported in naturalized sheep in Brazil, have now been documented in Santa Inês sheep (Ianella et al., 2009).

\section{Crossbreeding}

Most crossbreeding studies in Brazil are related to characteristics involving lamb growth (Malhado et al., 2009) and meat quality. The dam breed varies according to region with wool breeds being used in the South (Ribeiro et al., 2009) and Southeast and hair breeds being used in the Northeast and Centerwest, although hair breeds are also becoming more common in the Southeast (Furusho-Garcia et al., 2004). In these studies, rearing systems are also studied (Carvalho et al., 2005), comparing intensive and extensive systems and different sources of forage and protein (Carvalho et al., 2007) as well as sexual condition (Ribeiro et al., 2000). In particular it should be remembered that the pelt quality of hair sheep in higher than wool sheep or their crossbreds and crossbreeding can cause poorer pelt quality (Villarroel et al., 2004).

As there are so many crossbreeding studies in Brazil, it was decided not to cite individual papers. Table 6 shows the crosses used in studies in Brazil, usually using one or two crosses. Most studies have been carried out with Santa Inês as the dam breed and Texel the most popular sire breed.

Table 6 - Studies in crossbreeding sheep in Brazil

\begin{tabular}{|c|c|c|c|c|c|c|c|c|c|c|c|c|c|c|}
\hline \multirow[b]{2}{*}{ Ram } & \multicolumn{14}{|c|}{ Dam breed } \\
\hline & SI & PD & $\mathrm{MN}$ & $\mathrm{CO}$ & ID & SO & CR & $\mathrm{RM}$ & RL & $\mathrm{BE}$ & $\mathrm{PO}$ & SU & HD & $\mathrm{ME}$ \\
\hline DO & $\mathrm{X}$ & & $\mathrm{X}$ & & & & & & $\mathrm{X}$ & & & & & \\
\hline T X & $\mathrm{X}$ & & $\mathrm{X}$ & $X$ & $X$ & & & & & $X$ & $\mathrm{X}$ & $X$ & $\mathrm{X}$ & \\
\hline IF & $\mathrm{X}$ & & & $\mathrm{X}$ & & & & & & $\mathrm{X}$ & & & & $X$ \\
\hline HD & $\mathrm{X}$ & & & $\mathrm{X}$ & & & & & & & & & & \\
\hline SI & & $\mathrm{X}$ & $\mathrm{X}$ & & & $\mathrm{X}$ & $\mathrm{X}$ & & & & & $\mathrm{X}$ & & \\
\hline $\mathrm{BL}$ & & & & $\mathrm{X}$ & $\mathrm{X}$ & & & & & & $\mathrm{X}$ & & & \\
\hline $\mathrm{BE}$ & $\mathrm{X}$ & & & $\mathrm{X}$ & & & & & & & & & & \\
\hline $\mathrm{EF}$ & $\mathrm{X}$ & & & & & & & $\mathrm{X}$ & & & & & & \\
\hline SO & & & $\mathrm{X}$ & & & & $\mathrm{X}$ & & & & & & & \\
\hline SU & $\mathrm{X}$ & & & & & & & & & & & & & \\
\hline CAB & $X$ & & & & & & & & & & & & & \\
\hline PD & $X$ & & & & & $\mathrm{X}$ & & & & & & & & \\
\hline $\mathrm{DH}$ & $\mathrm{X}$ & & & & & $\mathrm{X}$ & & & & & & & & \\
\hline
\end{tabular}

DO - Dorper; SI - Santa Inês, MN - Morada Nova, CO - Corriedale, ID - Ideal, SO - somali, CR - Crioula, RM - Romney, BE - Bergamaica, PO - Polwarth, RL - Rabo Largo, SU - Suffolk, HD -Hampshore Down, ME - Merino, IF - Ile de France, TX - Texel, BL - Border Leicester, EF - East Friesian, CA - Cabugi, DH - Dorest Horn. 
In terms of carcass quality, while the market demands a standardized product, the diversity of breeds used in current production systems has resulted in large differences between carcass types (Cunha et al., 2000). Carcass traits are affected by slaughter weight (Pérez et al., 2007) and mature size (Lambe et al., 2007), as well as rearing system. Optimal slaughter weight is specific for each genotype, and its determination can help in obtaining carcasses of similar characteristics (Galvani et al., 2008). Depending on the system used, crossbreds are not necessarily better than purebreds (Rocha et al., 2009). While research concentrates on meat quality, few studies are looking at the female production for meat production, herd replacement and maintenance of crossbreed ewes resultant from these crosses.

\section{Interaction between classical and molecular genetics}

The use of molecular markers in animal breeding should concentrate on two fronts: those controlled by many genes of small effect, on which classical breeding is based or traits controlled by few genes of large effect. The latter have several examples in sheep such as those linked to prolificty (booroola, inverdale or galway), muscle mass (callipyge) or resistance/susceptibility to scrapie (PNRP). Castro et al. (2006) identified a mutation linked to prolificity specific to naturalized Brazilian breeds. This is at present being validated by Embrapa Recursos Genéticos e Biotecnologia and Embrapa Tabuleiros Costeiros.

In the former case, molecular markers may be useful where there is routine well structured performance recording which Lôbo \& Lôbo (2007) pointed out is lacking in Brazil. Van der Werf (2007) showed that developing countries should invest more in these recording programs than on molecular markers while Rocha et al. (2009) mentioned that there may be specific applications which have well defined objectives.

\section{Future and Final Considerations}

The predominant uses of selection using markers in sheep have been for scrapie resistance, high prolificacy and for increased size of higher value muscles. Emphasis is placed on selection for the favorable gene variant, and quantitative information is used to select within genotype. The sophisticated use of molecular and quantitative information on an industry-wide scale will require robust systems that can cope with imperfect data as well as development of selection indices to take full advantage of the information (Dodds et al., 2007). According to Green (2009) an area of major focus will be mining of the genomes through systems biology approaches to better understand gene and metabolic networks. Previously this has been relegated to into poorly understood genotype x environment and genotype $\mathrm{x}$ genotype interactions.

As in other countries, the successful merger of genomic and quantitative information in Brazil's sheep research is limited by the lack of adequate populations to appropriately define and measure phenotypes (i.e., the so-called phenomic gap) for difficult-to-measure traits such as resistance to disease and stress, adaptability, longevity, and efficiency of nutrient utilization. The lack of academics with the necessary skills in data mining and analysis is also a worldwide problem.

Research in other countries could be applied in Brazil. Studies report the successful development of a $20 \mathrm{~K}$ bovine expression array used to study transcriptional profiles of sheep resistant and susceptible to gastrointestinal (GI) nematodes (Keane et al., 2006), and other successful examples of cross-species hybridisation of sheep samples on bovine arrays (Diez-Tascon et al., 2005; Cao et al., 2006). A $15 \mathrm{~K}$ expression chip developed by Agilent is also available. For example, mastitis has been shown to be heritable (Fragkou et al., 2007) and can cause reduced milk production, weaning weights due to a drop in milk production and altered suckling behaviour (Gougoulis et al., 2008), with lamb mortality from starvation in extreme cases. QTL have been identified in traits that are known to influence mastitis susceptibility and resistance (Barillet et al., 2005) as well as udder shape (Legarra \& Ugarte, 2005).

Brazil is the only South American country (financed by EMBRAPA Macroprograma 1 Animal Genomics) participating in the Sheep HapMap project (ISGC - http:// www.sheephapmap.org/) using 60.000 SNP (Single Nucleotide Polymorphism) markers in genotyping more than 50 breeds and 2000 animals worldwide. Samples from three naturalized breeds (Santa Inês, Morada Nova and Crioula Lanada) are presently being analysed and initial results show that Brazilian breeds have two sources of variation (the Mediterranean and Africa), while European breeds have three closely related sources and African breeds a single source. Brazilian breeds therefore represent both these continents. These new techniques together with advances in statistical methods should bring new opportunities for sheep research and production in Brazil. At present projects such as National Institute for Science and Technology - Information on Brazilian Domestic Animal Genetics and Health, using landscape genetics technologies to link environments with alleles together with statistical technologies being developed in 
EMBRAPA's Animal Genomics program should bring important new developments and information for sheep breeding in Brazil.

\section{Acknowledgements}

CNPq - INCT-IGSPB and EMBRAPA Macroprograma 1 - Genomica Animal.

\section{References}

AMARANTE, A.F.T.; BRICARELlo, P.A.; ROCHA, R.A. Resistance of Santa Inês, Suffolk and Ile de France lambs to naturally acquired gastrointestinal nematode infections. Veterinary Parasitology, v.120, n.1, p.91-106, 2004.

AMARANTE, A.F.T.; SUSIN, I.; R.A. ROCHA, M.B. et al. Resistance of Santa Inês and crossbred ewes to naturally acquired gastrointestinal nematode infections. Veterinary Parasitology, v.165, n.12, p.273-280, 2009.

BANDELT, H.J.; FORSTER, P.; ROHL, A. Median-joining networks for inferring intraspecific phylogenies. Molecular Biology and Evolution, v.16, n.1, p.37-48, 1999.

BANOS, G.; WIGGANS, G.R.; POWELL, R.L. Impact of paternity errors in cow identification on genetic evaluations and international comparisons. Journal of Dairy Science, v.88, n.11, p.2523-2529, 2001.

BARILLET, F.; ARRANZ, J.J.; CARTA, A. Mapping quantitative trait loci for milk production and genetic polymorphisms of milk proteins in dairy sheep. Genetics, Selection, Evolution, v.37, n.1, p.109-123, 2005.

BARON, E.E.; MARTINEZ, M.L.; VERNEQUE, R.S. et al. Parentage testing and effect of misidentification on the estimation of breeding value in Gyr cattle. Genetics and Molecular Biology, v.25, n.4, p.389-394, 2002.

BRICARELLO, P.A.; AMARANTE, A.F.T.; ROCHA, R.A. et al. Influence of dietary protein supply on resistance to experimental infections with Haemonchus contortus in Ile de France an Santa Inês lambs. Veterinary Parasitology, v.134, n.11, p.99-109, 2005.

CAO, H.; KABAROFF, L.C.; YOU, Q. et al. Characterization of ovine hepatic gene expression profiles in response to Escherichia coli lipopolysaccharide using a bovine cDNA microarray. BMC Veterinary Research, v.2, n.34, 2006.

CARDELLINO, R.A.; OSORIO, J.C.S.; GUERREIRO, J.L.V. Genetic parameters of wool production traits for Corriedale sheep in Southern Brazil. Revista Brasileira de Genética, v.10, n.3, p.507-515, 1987.

CARNEIRO, H.C.R.; PAIVA, S.R.; PAIM, T.P. et al. Estudo piloto da análise de viabilidade populacional de uma população de ovinos Santa Inês do Distrito Federal. In: SIMPOSIO DE RECURSOS GENÉTICOS PARA AMÉRICA LATINA Y EL CARIBE, 2009, Pucon. Proceedings... Pucon, 2009.

CARNEIRO, P.L.S.; AZEVEDO, D.M.M.R.; MALHADO, C.H.M. et al. Estudo de populações de ovinos Santa Inês utilizando técnicas de análise multivariada. Revista Científica de Produção Animal, v.8, n.1, p.38-48, 2006.

CARVALHO, S.; BROCHIER, M.A.; PIVATO, J. et al. Ganho de peso, características da carcaça e componentes não-carcaça de cordeiros da raça Texel terminados em diferentes sistemas alimentares. Ciência Rural, v.37, n.3, p.821-827, 2007.

CARVAlHo, S.; VERGUEIRO, A.; KIELING, R. et al. Desempenho e características da carcaça de cordeiros das raças Texel, Suffolk e cruza Texel x Suffolk. Ciência Rural, v.35, n.5, p.1155-1160, 2005.
CASTRO, E.A.; LOPEZ, I.M.R.; LIM, A. et al. Characterization of a new SNP in the growth and differentiation factor 9 (GDF- 9) gene, specific for the Brazilian Santa Inês sheep. In: PROCEEDINGS OF THE 8TH WORLD CONGRESS ON GENETICS APPLIED TO LIVESTOCK PRODUCTION, 8., 2006, Belo Horizonte. Proceedings... Belo Horizonte, 2006.

CORREA, G.F.; OSÓRIO, M.T.M.; KREMER, R. et al. Produção e composição química do leite em diferentes genótipos ovinos. Ciência Rural, v.36, n.3, p.936-941, 2006.

CUNHA, E.A.; SANTOS, L.E.; BUENO, M.S. et al. Utilização de carneiros de raças de corte para obtenção de cordeiros precoces para abate em plantéis produtores de lã. Revista Brasileira de Zootecnia, v.29, n.1, p.243-252, 2000.

DIEZ-TASCON, C.; KEANE, O.M.; WILSON, T. et al. Microarray analysis of selection lines from outbred populations to identify genes involved with nematode parasiteresistance in sheep. Physiological Genomics, v.21, n.1, p.56-69, 2005.

DODDS, K.G.; MCEWAN, J.C.; DAVIS, G.H. Integration of molecular and quantitative information in sheep and goat industry breeding programmes. Small Ruminant Research, v.70, n.6, p.32-41, 2007.

EMEDIATO, M.S.; SIQUEIRA, E.R.; STRADIOTTO, M.M. et al. Queijo tipo prato de leite de ovelhas alimentadas com dieta contendo gordura protegida. Veterinária e Zootecnia, v.16, n.1, p.228-238, 2009.

ENSMINGER, M.E.; PARKER, R.O. Sheep and goat science. 5.ed. Danville, Illinois: The Interstate Printers and Publishers, 1986.

FNP Instiute, Anualpec 2009, Agra FNP Pesquisas Ltda, 2009, 360 p.

FRAGKOU, I.A.; SKOUFOS, J.; CRIPPS, P.J. et al. Differences in susceptibility to Mannheimia haemolytica-associated mastitis between two breeds of dairy sheep. Journal of Dairy Research, v.74, n.3, p.349-355, 2007.

FURUSHO-GARCIA, I.F.; PEREZ, J.R.O.; BONAGURIO, S. et al. Desempenho de cordeiros Santa Inês puros e cruzas Santa Inês com Texel, Ile de France e Bergamácia. Revista Brasileira de Zootecnia, v.33, n.6, p.1591-1603, 2004.

GALLOWAY, S.M.; MCNATTY, K.P.; CAMBRIDGE, L.M. et al. 2000. Mutations in an oocyte-derived growth factor gene (BMP 15) cause increased ovulation rate and infertility in a dosagesensitive manner. Nature Genetics, v.25, n.7, p.279-83, 2000.

GALVANI, D.B.; PIRES, C.C.; KOZLOSKI, G.V. et al. Energy requirements of Texel crossbred lambs. Journal Animal Science, v.86, n.12, p.3480-3490, 2008.

GÂNDAVO, P.M. Tratado da Terra do Brasil - História da Província de Santa Cruz. Belo Horizonte: Itatiaia, 1980. 150p.

GOUGOULIS, D.A.; KYRIAZAKIS, I.; PAPAIOANNOU, N. et al. Subclinical mastitis changes the patterns of maternal-offspring behaviour in dairy sheep. The Veterinary Journal, v.176, n.3, p.378-384, 2008.

GREEN, R.D. ASAS Centennial Paper: Future needs in animal breeding and genetics. Journal of Animal Science, v.87, n.2, p.793-800, 2009.

HAYES, B.; SONNESON, A.K.; GJERDE, B. Evaluation of three strategies using DNA markers for traceability in aquaculture species. Aquaculture, v.250, n.1-2, p.70-81, 2005.

HEGGEBØ R.; PRESS C.M.; GUNNES G. et al. Distribution and accumulation of PrP in gut-associated and peripheral lymphoid tissue of scrapie-affected Suffolk sheep. Journal of General Virology, v.83, n.2, p.479-489, 2002.

HENDERSON, C.R. Application of linear models in animal breeding. Guelph: University of Guelph, 1984.

HIENDLEDER S.; SCHMUTZ, S.M.; ERHARDT, G. et al. Transmitochondrial differences and varying levels of heteroplasmy in nuclear transfer cloned cattle. Molecular Reproduction and Development, v.54, n.1, p.24-31, 1999.

IANELLA, P.; McMANUS, C.; CAETANO, A.R. et al. Avaliação dos polimorfismos do gene PRNP ligados a scrapie clássica em 
núcleos de conservação de ovinos do Brasil. In: SIMPOSIO DE RECURSOS GENETICOS DA AMERICA LATINA Y EL CARIBE, 7., 2009, Pucon. Proceedings... Pucon: 2009. v.2, p. 265-266.

JACINTO, M.A.C.; SOBRINHO, A.G.S.; COSTA， R.G. Características anátomo-estruturais da pele de ovinos (Ovis áries L.) lanados e deslanados, relacionadas com o aspecto físicomecânico do couro. Revista Brasileira de Zootecnia, v.33, n.4, p.1001-1008, 2004.

JIMENEZ-GAMERO, I.; MUNOS-SERRANO, A.; ANALLA, M. et al. DNA microsatellites to ascertain pedigree recorded information in a selecting nucleus of Murciano-Granadina daily goats. Small Ruminant Research, v.65, n.3, p.266-273, 2006.

JOHNSON, P.L.; MCEWAN, J.C.; DODDS, K.G. et al. A directed search in the region of GDF8 for quantitative trait loci affecting carcass traits in Texel sheep. Journal of Animal Science, v.83, n.9, p.1988-2000, 2005

KEANE, O.M.; ZADISSA, A.; WILSON, T. et al. Gene expression profiling of naïve sheep genetically resistant and susceptible to gastrointestinal nematodes. BMC Genomics, v.7, n.3, 2006.

LAMBE, N.R.; NAVAJAS, E.A.; MCLEAN, K.A. et al. Changes in carcass traits during growth in lambs of two contrasting breeds, measured using computer tomography. Livestock Science, v.107, n.3, p.37-52, 2007.

LEGARRA, A.; UGARTE, E. Genetic parameters of udder traits, somatic cell score, and milk yield in Latxa sheep. Journal of Dairy Science, v.88, n.6, p.2238-2245, 2005.

LÔBO, A.M.B.O.; LÔBO, R.N.B.; PAIVA, S.R. Aromatase gene and its effects on growth, reproductive and maternal ability traits in a multibreed sheep population from Brazil. Genetics and Molecular Biology, v.32, n.3, p.484-490, 2009 b.

LÔBO, A.M.B.O.; LÔBO, R.N.B.; PAIVA, S.R. et al. Genetic parameters for growth, reproductive and maternal traits in a multibreed meat sheep population. Genetics and Molecular Biology, v.32, n.4, p.761-770, 2009a.

LÔBO, R.N.B.; VILLELA, L.C.V.; LÔBO, A.M.B.O. et al Parâmetros genéticos de características estimadas da curva de crescimento de ovinos da raça Santa Inês. Revista Brasileira de Zootecnia, v.35, n.3, p.1012-1019, 2006.

LÔBO, R.N.B.; LÔBO, A.M.B.O. Melhoramento genético como ferramenta para o crescimento e o desenvolvimento da ovinocultura de corte. Revista Brasileira de Reprodução Animal, v.31, n.2, p.247-253, 2007.

LÔBO, R.N.B.; VIEIRA, L.S.; OLIVEIRA, A.A. et al. Genetic parameters for fecal egg count, packed cell volume and body weight of Santa Inês lambs. Genetics and Molecular Biology, v.32, n.2, p.288-294, 2009.

LOUVANDINI, H.; VELOSO, C.F.M.; PALUDO, G.R. et al. Influence of protein supplementation on the resistance and resilience on young hair sheep naturally infected with gastrointestinal nematodes during rainy and dry seasons. Veterinary Parasitology, v.137, n.4, p.103-111, 2006.

MALHADO, C.H.M.; CARNEIRO, P.L.S.; AFFONSO, P.R.A.M. et al. Growth curves in Dorper sheep crossed with the local Brazilian breeds, Morada Nova, Rabo Largo, and Santa Inês. Small Ruminant Research, v.84, n.6, p.16-21, 2009.

MINISTÉRIO DA AGRICULTURA, PECUÁRIA E ABASTECIMENTO - MAPA. Intercâmbio comercial do agronegócio: principais mercados de destino. Brasília: 2009. 469p.

MARIANTE, A.S.; McMANUS, C.; MENDONÇA, J.F. Country report of animal genetic eesources. Brasília: EMBRAPA, 2003. 91p.

MARIANTE, A.S.; CAVALCANTE, N. Animals of the discovery: domestic breeds in the history of Brazil. 2.ed. Brasília: EMBRAPA, 2006. 232p.

McMANUS, C.; MIRANDA, R.M. Estimativas de parâmetros genéticos em ovinos Bergamacia. Revista Brasileira de Zootecnia, v.27, n.5, p.916-921,1998.
McMANUS, C.; PINTO, B.; LOUVANDINI, H. et al. Selection objectives for hair sheep in central Brazil. In: WORLD CONGRESS ON GENETICS APPLIED TO LIVESTOCK PRODUCTION, 8., 2006, Belo Horizonte. Proceedings... Belo Horizonte, 2006. 4p.

McMANUS, C.; PALUDO, G.R.; LOUVANDINI, H. et al. Heat tolerance in Brazilian sheep: physiological and blood parameters. Tropical Animal Health and Production, v.41, n.1, p.95-101, 2009a.

McMANUS, C.; PRESCOTT, E.; PALUDO, G.R. et al. Heat tolerance in naturalized Brazilian cattle breeds. Livestock Science, v.120, n.3, p.256-264, 2009b.

MEADOWS, J.R.S.; LI, K.; KANTANEN, J. et al. Mitochondrial sequence reveals high levels of gene flow between breeds of domestic sheep from Asia and Europe. Journal of Heredity, v.96, n.5, p.494-501, 2005.

MEADOWS, J.R.; HANOTTE, O.; DRÖGEMÜLLER, C. et al. Globally dispersed $\mathrm{Y}$ chromosomal haplotypes in wild and domestic sheep. Animal Genetics, v.37, n.5, p.444-453, 2006.

MORAIS, O.R. Valores econômicos para características de produção de ovinos Santa Inês. 2005. 50f. Tese (Doutorado em Ciências Animal) - Universidade Federal de Minas Gerais, Belo Horizonte.

NESPOLO, C.R.; TAFFAREL, J.A.S.; BRANDELLI, A. Parâmetros microbiológicos e físico-químicos durante a produção e maturação do queijo Fascal. Acta Scientiae Veterinariae, v.37, n.4, p.323-328, 2009.

NIETO, L.M.; MARTINS, E.N.; MACEDO, F.A.F. et al. Utilização de um modelo de limiar na estimação da herdabilidade de resistência dos ovinos aos endoparasitos. Acta Scientiarum, v.25, n.1, p.151-155, 2003.

NOTTER, D.R. The importance of genetic diversity in livestock populations of the future. Journal of Animal Science, v.77, n.1, p.61-69, 1999.

OJEDA, D.B. Participação do melhoramento genético na produção ovina. Revista Brasileira de Reprodução Animal, v.23, n.2, p.146-149, 1999.

PAIVA, S.R. Caracterização da diversidade genética de ovinos no Brasil com quatro técnicas moleculares. 2005. 108f. Tese (Doutorado em Genética e Melhoramento) Universidade Federal de Viçosa, Viçosa, MG.

PAIVA, S.R.; FARIA, D.A.; DERGAM, J. et al. Genetic structure of hair sheep breeds in Brazil by microsatellites markers. In: INTERNATIONAL CONFERENCE ON ANIMAL GENETICS, 30., 2006, Porto Seguro. Proceedings... Porto Seguro, 2006.

PAIVA, S.R.; SilvÉRIO, V.C.; EGITO, A.A. et al. Genetic variability of the Brazilian hair sheep breeds. Pesquisa Agropecuaria Brasileira, v.40, n.9, p.887-893, 2005.

PARISET, L.; SAVARESE, M.C.; CAPPUCCIO, I. et al. Use of microsatellites for genetic variation and inbreeding analysis in Sarda sheep flocks of central Italy. Journal Animal Breeding and Genetics, v.120, n.12, p.425-432, 2003.

PEDROSA, S.; UZUN, M.; ARRANZ, J.J. et al. Evidence of three maternal lineages in near eastern sheep supporting multiple domestication events. Proceedings of the Royal Society of London, v.272, n.9, p.2211-2217, 2005.

PEREIRA, I.D.C. Estimativas de pesos econômicos para um sistema de produção de ovinos da raça Morada Nova, no semi-árido brasileiro. 2010. 49f. Dissertação (Mestrado em Zootecnia) Universidade Federal do Ceará, Fortaleza.

PÉREZ, P.; MAINO, M.; MORALES, M. et al. Gender and slaughter weight effects on carcass quality traits of suckling lambs from four different genotypes. Small Ruminant Research, v.70, n.10, p.124-130, 2007.

PETROLI, C.D. Marcadores microssatélites no MHC de ovinos: estudos de associação. 2007. 84f. Dissertação (Mestrado em Ciências Animais) - Universidade de Brasília, Brasília. 
PETROLI, C.D.; PAIVA, S.R.; CORREA, M.P.C. et al. Genetic monitoring of a Santa Inês herd using microsatellite markers near or linked to the sheep MHC. Revista Brasileira de Zootecnia, v.38, n.4, p.670-675, 2009.

PINHEIRO JR., G.C. Ovinos no Brasil. Belo Horizonte: Itataia Ltda., 1973. 224p.

PLASTOW, G.S.; MILEHAM, A.J.; WILKEN, T. et al. Pig Improvement Company (UK) Ltda, assignee. System for tracing animal products. US patent 7229764, 2007.

PRIMO, A.T. América: conquista e colonização. Porto Alegre: Movimento, 2004. 183p.

PRIMO, A.T. The discovery of Brazil and the introduction of domestic animals. In: GLOBAL CONFERENCE ON CONSERVATION OF DOMESTIC ANIMAL GENETIC RESOURCE, 5., 2000, Brasília. Proceedings... Brasília: Embrapa Recursos Genéticos e Biotecnologia, 2000. (CD-ROM)

QUESADA, M.; McMANUS, C.; D’ARAUJO COUTO, F.A. Efeitos genéticos e fenotípicos sobre características de produção e reprodução de ovinos deslanados no Distrito Federal. Revista Brasileira de Zootecnia, v.31, n.1, p.342-349, 2002.

RIBEIRO, E.L.A.; OLIVEIRA, H.C.; CASTRO, F.A.B. et al. Desempenho em confinamento e componentes do peso vivo de cordeiros mestiços de três grupos genéticos. Ciência Rural, v.39, n.7, p. 2162-2168, 2009.

RIBEIRO, E.L.A.; ROCHA, M.A.I.; MIZUBUTI, Y. et al. Ganho de peso e componentes do peso vivo em borregos Ile de France inteiros ou castrados e Hampshire Down castrados abatidos aos doze meses de idade. Ciência Rural, v.30, n.2, p.333-336, 2000.

RIBEIRO, L.C.; PÉREZ, J.R.O.; CARVALHO, P.H.A. et al. Produção, composição e rendimento em queijo do leite de ovelhas Santa Inês tratadas com ocitocina. Revista Brasileira de Zootecnia, v.36, n.2 p.438-444, 2007.

RIBEIRO, M.N.; CRUZ, G.R.B.; OJEDA, D.B. Recursos genéticos de pequenos ruminantes na América do Sul e estratégia de conservação. Revista Brasileira de Zootecnia, v.35, p.800817, 2006 (supl. esp.).

RIPLEY, G.; DANA, C.A. The American cyclopaedia. D. Appleton and Company, 1875.

ROCHA, L.P. FRAGA, A.B.; ARAÚJO FILHO, J.T. et al. Desempenho de cordeiros cruzados em Alagoas, Brasil. Archivos de Zootecnia, v.58, n.221, p.145-148, 2009.

RODERO, A.; DELGADO, J.V.; RODERO, E. Primitive Andalusian livestock and their implication in the Discovery of America. Archivos de Zootecnia, v.41, n.154, p383-400, 1992.

RYDER, M.L. Sheep and man. London: Gerald Duckworth, 1983.

SA, C.O.; SIQUEIRA, E.R.; SA, J.L. et al. Influência do fotoperíodo no consumo alimentar, produção e composição do leite de ovelhas Bergamácia. Pesquisa Agropecuária Brasileira, v.40, n.6, p.601-608, 2005.

SARMENTO, J.L.R.; TORRES, R.A.; SOUSA, W.H. et al. Estimação de parâmetros genéticos para características de crescimento de ovinos Santa Inês utilizando modelos uni e multicaracterísticas. Arquivo Brasileiro de Medicina Veterinária e Zootecnia, v.58, n.4, p.581-589, 2006.

SCHERF, B.D. World watch list for domestic animal diversity. 3.ed. Rome: FAO, 2000

SENNEKE, S.L.; MAC NEIL, M.D.; VAN VLECK, L.D. Effect of sire misidentification on estimates of genetic parameters for birth and weaning weights in Hereford cattle. Journal of Animal Science, v.82, n.8, p.2307-2312, 2004.

SILVA, F.L.R.; ARAÚJO, A.M. Características de reprodução e de crescimento de ovinos mestiços Santa Inês, no Ceará. Revista Brasileira de Zootecnia, v.29, n.6, p.1712-1720, 2000.

SILVÉRIO, V.C.; PAIVA, S.R.; FARIA, D.A. et al. Phylogenetic study on the main brazilian naturalized sheep breeds. In: 8th World Congress on Genetics Applied to Livestock Production, 8., 2006, Belo Horizonte. Proceedings... Belo Horizonte: 2006. (CD-ROM).

SMITH, M.S.; BARBARA, M.A.; KENNEDY, G. Beginning shepherd's manual. 2.ed. Ames: Iowa State University Press, 1997.

SOUSA, G.S. Tratado descritivo do Brasil em 1587. 3.ed. São Paulo: Cia Editora Nacional/ Brasiliana, 1938. 493p.

SOUSA, W.H.; PEREIRA, C.S.P.; BERGMANN, A.G. et al. Estimativas de componentes de (co)variância e herdabilidade direta e materna de pesos corporais em ovinos da raça Santa Inês. Revista Brasileira de Zootecnia, v.28, n.6, p.12521262, 1999.

SOUSA, J.E.R.; OLIVEIRA, S.M.P.; LIMA, F.A.M. et al. Efeitos genéticos e de ambiente para características de crescimento em ovinos Santa Inês no Estado do Ceará. Revista Ciência Agronômica, v.37, n.3, p.364-368, 2006.

SOUZA, W.; PEREIRA, C.S.; BERGMANN, J.A.G. et al. Estimativa de componentes de variância e de parâmetros genéticos para características e reprodução por intermédio de modelos lineares e de limiar. Revista Brasileira de Zootecnia, v.29, n.6, p.2237-2247, 2000.

SOUZA, W.H.; LÔBO, R.N.B.; MORAIS, O.R. Ovinos Santa Inês: estado da arte e perspectivas. In: INTERNATIONAL SYMPOSIUM ON SHEEP AND GOAT PRODUCTION, 2., 2003, João Pessoa. Anais... João Pessoa: 2003. p.501-522.

SOUZA, A.C.K.O.; OSÓRIO, M.T.M.; OSÓRIO, J.C.S. et al. Produção, composição química e características físicas do leite de ovinos da raça Corriedale. Revista Brasileira de Agrociência, v.11, n.1, p. 73-77, 2005.

SOUZA, C.A.; PAIVA, S.R.; FARIA, D.A. et al. Allele frequency of 23 STRs loci among five populations of Santa Inês hair sheep breed in Brazil. In: 30th INTERNATIONAL CONFERENCE ON ANIMAL GENETICS - ISAG, 30., 2006, Porto Seguro. Proceedings... Porto Seguro, 2006.

VAN DER WERF, J.H. Marker-assisted selection in sheep and goats. In: GUIMARÃES, E.; RUANE, J.; SCHERF, B. et al. (Eds.). Marker-assisted selection - current status and future perspectives in crops, livestock, forestry and fish. Roma: FAO, 2007. p.230-247.

VILLARROEL, A.B.S.; COSTA, R.G.; OLIVEIRA, S.M.P. Características físico-mecânicas do couro de ovinos mestiços Santa Inês e Texel. Revista Brasileira de Zootecnia, v.33, n.6, p.2373-2377, 2004

VISSCHER, P.M.; WOOLLIAMS, J.A.; SMITH, D. et al. Estimation of pedigree errors in the UK dairy population using microsatellite markers and the impact on selection. Journal of Dairy Science, v.85, n.9, p.2368-2375, 2002.

WELLER, J.I.; FELDMESSER, E.; GOLIK, M. et al. Factors affecting incorrect paternity assignment in the Israeli Holstein population. Journal of Dairy Science, v.87, n.8, p.2627-2640, 2004. 